\title{
sciendo
}

\section{Considerations on support active measures applicable in Romania in the context of the epidemiological situations due to the spread of SARS-CoV-2 coronavirus}

\author{
Ana VIDAT \\ Bucharest University of Economic Studies, Bucharest, Romania \\ ana.vidat@drept.ase.ro \\ Brândușa Oana TELEAOACA-VARTOLOMEI \\ Bucharest University of Economic Studies, Bucharest, Romania \\ brandusa.vartolomei@drept.ase.ro
}

\begin{abstract}
The epidemiological crisis caused by the SARS-CoV-2 virus has led to the need to adapt national legislation to safeguard jobs and to decrease the unemployment rate - realities existing at European and international level - by providing financial facilities to employers and employees. This paper presents and analyses the relevance of the legal rules adopted in this field.
\end{abstract}

Keywords: individual employment contract; technical unemployment; facilities for employees and employers; suspension of the individual employment contract; SARS-CoV-2.

\section{Introduction}

In the current context caused by the global spread of the SARS-CoV-2 virus - which has generated negative, socio-economic consequences with a major impact on the labour force and unemployment rate - it was a priority, on the one hand, to provide national support to both employees and employers to resume economic activity as well as to invigorate employers by active measures to attract available labour force, including from areas for which activity has been restricted (Order No. 1109/2974/2020).

In keeping with the objectives set at European level, Romania adopted Government Emergency Ordinance No. 92/2020, a regulatory act designed to establish support measures to strengthen the labour market, while preventing the increase in the unemployment rate at national level, as well as providing financial aid to employers to support the payment of employees' salaries, thereby helping to reduce the negative social effects caused by the spread of the SARS-CoV-2 virus.

\section{Measures contained in the regulatory act}

From the point of view of labour law, the following categories of provisions are relevant - for this study, which concern:

- providing facilities to employers and employees;

- the sanctioning legal regime applicable to both employees and employers in the event of noncompliance with the legal provisions. 


\section{Conditions for granting facilities}

From June $1^{\text {st }}, 2020$, for a period of three months, employers shall receive the settlement of part of the salary, borne from the unemployment insurance budget representing $41.5 \%$ of the gross basic salary corresponding to the job occupied, but not more than $41.5 \%$ of the average gross earnings (Government Emergency Ordinance No. 92/2020).

Are excluded from the granting of these amounts (according to article $\mathrm{V}$ paragraph 1 from normative act):

- public institutions/authorities (Ștefănescu, 2017) - we consider that, from a terminological point of view, the legislature uses the concept of 'worker', without taking into account the fact that legal employment relationships are intended to be performed by employees, excluding aspects of civil servants' service relationships.

- employers who at the time of the request for these amounts are in bankruptcy, dissolution, liquidation or who have their activities suspended or restricted for other reasons than those arising from the spread of the SARS-CoV-2 coronavirus.

Employers with more than one activity object, at least one of whom is subject to the restrictions, will choose:

- for the settlement of $41.5 \%$ of the gross basic salary;

- to continue to apply the provisions relating to the granting of technical unemployment benefits and after 31 May 2020 until the restrictions are lifted.

In the case of employees, in order to benefit from the facilities provided by the Government Emergency Ordinance, they must:

- have previously received the technical unemployment benefit from the unemployment insurance budget in accordance with article XI pargraph 1 from Government Emergency Ordinance No. 30/2020 or, to have had individual employment contracts suspended pursuant to Article 52 paragraph 2 of the Labour Code - and without being applicable the provisions of Article XI from Government Emergency Ordinance No. 30/2020 during the state of emergency or alert;

- have had individual employment contracts suspended for a minimum of 15 days during the state of emergency or alert;

- have benefited either from the amounts provided for in articles XI and XV from the Government Emergency Ordinance No. 30/2020 (technical unemployment allowance or specific allowance for other professionals, athletes, lawyers, persons earning income from copyright) or by the provisions of article 53 from the Labour Code (indemnity paid from the salary fund).

These measures shall also include persons who have individual labour agreements concluded under Law No. 1/2005 on the organisation and functioning of cooperation.

The only requirement legally imposed on employers to benefit from the facilities in the Government Emergency Ordinance is to maintain employment relations until December $31^{\text {st }}, 2020$, with the exception of seasonal workers.

This duty shall not apply where termination of the individual employment contract occurs for reasons not attributable to the employer. It is regrettable the error of the legislature regarding the termination of the individual employment contract by using the phrase 'for reasons not attributable to the employer', taking into account the fact that, within the meaning of the Labour Code (Law No. 53/2003), the termination of the individual employment contract may take place on the employer's initiative for reasons which are not related to the person of the employee (article 61 et seq. in conjunction with article 65 et seq. of the Labour Code). 


\section{Penalties applicable in the event of non-compliance with legal obligations}

Employers who terminate the individual employment contracts of employees before the terms imposed by the Government Emergency Ordinance shall be obliged to return, in full, to the employment agencies - if their termination took place pursuant to Article 55 pargraph b (end by agreement), article 56 pargraph 1 letter d (cessation due to the finding of nullity of the individual employment contract) and e (cessation as a result of the admission of the application for reintegration) and article 65 (dismissal for reasons not related to the employee) of the Labour Code the amounts received for each person for whom the employment relationship before that period has ceased and the reference interest of the BNR in force at the time of termination of individual employment contracts (art. IV of the Government Emergency Ordinance). As noted, cases of termination of individual employment contracts do not imply the guilt of employees.

\section{Procedural aspects}

a) In order to be able to settle the amounts provided for by the Government Emergency Ordinance, employers shall bear the full wage consideration and thereafter, from the first date until the $25^{\text {th }}$ of the month following the reporting period to which the income relates, they shall deposit, by electronic means, with the employment agencies within the range of which they have their registered office:

- signed and dated application;

- declaration on his own responsibility; and

- the list of persons benefiting from this amount.

b) Settlement shall be made no later than 10 days after the date on which the employers fulfil their declaratory and payment obligations relating to income from wages and salaries in the reporting period for which the request is made.

c) Amounts shall be granted from the unemployment insurance budget, within the approved budget, by transfer to accounts opened by employers.

It follows from the content of the article III paragraph 4 from Government Emergency Ordinance that the amounts of financial support for the partial coverage of employees' salaries do not add up to the subsidies to be granted to employees for whom employers have concluded contracts or agreements with employment agencies under Law No. 76/2002 on the unemployment insurance system and the stimulation of employment.

\section{Incentives granted by the State in the case of staff employment}

In order to prevent the loss of jobs and the increase in the unemployment rate, the legislature instituted the following financial incentives:

- Employers who, between 1 June 2020 and 31 December 2020, employ persons over 50 years of age whose employment relationships have ceased for reasons beyond their control, during the period of the state of emergency or the state of alert, registered as unemployed in the register of employment agencies, shall receive monthly, for a period of 12 months, for each person employed in this category, $50 \%$ of the employee's salary, but not more than 2,500 lei.

- Employers who are employed, but not later than 31 December 2020, for an indefinite period, fulltime, persons aged between 16 and 29 years, registered as unemployed in the employment agencies' register, receive monthly, for a period of 12 months, for each person employed in this category, $50 \%$ of the employee's salary, but not more than 2,500 lei.

Consequently, those who undertake on the basis of an individual contract of employment, concluded for an indefinite period, but only with normal working hours, according to the legal 
provisions in force, benefit from the monthly amount of employment; the individual fixed-term employment contract and part-time work schedule are thus excluded.

Of course, these amounts are not granted to employees of public institutions/authorities or employers who at the time of the request for these amounts are in bankruptcy, dissolution, liquidation or who have suspended or restricted activities for reasons other than those arising from the spread of the SARS-CoV-2 coronavirus.

In both cases highlighted, the condition imposed by the Government Emergency Ordinance is that employers maintain employment relations for a period of at least 12 months from the expiry of the 12 months period provided for by the regulatory act.

Employers who terminate employees' employment contracts before the time limits imposed shall be obliged to reimburse, in full, to the employment agencies the amounts received for each person for whom the employment relationship has ceased before that period, plus the reference interest of the BNR in force at the time of termination of the individual employment contracts, if their termination took place pursuant to article 55 pargraph b) (end by agreement), article 56 parhraph 1 letter $d$ (cessation due to the finding of nulity of the individual contract of employment) and e (cessation as a result of the admission of the application for reintegration) and article 65 (dismissal for reasons not related to the employee) of the Labour Code.

The amounts provided for shall be granted for the payment of the salary in proportion to the time actually worked by the employee in that month.

These amounts shall not be aggregated, for the same employee, with the subsidies to be granted to employers who have concluded contracts or agreements with employment agencies pursuant to Law No. 76/2002.

The amounts provided for shall also be granted for the period of rest leave.

During the period in which employment relationships are suspended, the amounts provided for shall not be granted. This measure is an exception to the rule laid down in article 49 pargraph 1 from the Labour Code according to which 'during the suspension there may continue to be rights and obligations of the parties other than those referred to in paragraph 2 if they are provided by special laws, by the applicable collective agreement, by individual contracts of employment or by internal regulations.'

All provisions also apply to the employment of Romanian citizens who have ceased their employment relations with foreign employers in progress in the territory of other States, for reasons beyond their control, by dismissal.

Amounts shall be granted (Order No. 456/2020) from the unemployment insurance budget, at the request of employers, submitted by electronic means to employment agencies within the scope of which they have their registered office.

\section{Conclusion}

From the perspective of legal employment relationships, the legal texts establish a benefit for the employers who falls into work on the basis of individual employment contracts concluded for an indefinite period only with normal working hours; are thus excluded from the scope of the normative act individual fixed-term and part-time employment contracts.

Although, over time, through the amendments and additions to the Labour Code, a flexibility of the legal regime applicable to the individual fixed-term employment contract has been made, employers who employ employees on the basis of one of the same employment contracts do not benefit from the facilities provided by the Government Emergency Ordinance. 
The legislator, in his constant approach, has stimulated the conclusion of individual contracts of employment of indefinite duration - which constitutes for employees a protective measure, aimed at ensuring the right to stability in the workplace, and for employers conferring the possibility to better plan and organize their work, to shape and improve the qualification of staff.

Although the changes made over time to the Labour Code have expressed a real concern about the reputedity of the relatively precarious nature (Ștefănescu, 2017, Dimitriu, 2016, Marica, 2019, Dumitru, Stoican, 2019) of the individual fixed-term employment contract and that of the part-time contract, it is noted from the analysis of those texts that those contracts still maintain that character, even if they have diminished to some extent.

In conclusion, the regulations contained in Government Emergency Ordinance No. 92/2020 without responding to all the challenges of the Romanian practice, aim to create a legal framework appropriate to the conduct of employment relations in the conditions of the global epidemiological crisis.

\section{References}

Dimitriu, R. (2016). Dreptul muncii. Anxietăţi ale prezentului, Bucharest, Rentrop \& Straton Publishing House.

Dumitru, O.I., Stoican, A. (2019). Business Law. Lecture notes, Bucharest, ASE Publishing House. Government Emergency Ordinance No. 92/2020, Published in Official Gazette, part I, no. 459 from 29 May 2020.

Government Emergency Ordinance No. 30/2020, Published in Officiale Gazette, part I, no. 231 from 30 March 2020.

Labor Code, Romania, Republished in Official Gazette, part I, no. 345 from 18 May 2011, with subsequent amendments and additions.

Law No. 1/2005 on the organisation and functioning of cooperation, Published in Official Gazette, part I, no. 368 from 20 May 2014.

Law No. 76/2002 on the unemployment insurance system and the stimulation of employment, Published in Official Gazette, part I, no. 103 from 6 February 2002, with subsequent amendments and additions.

Marica, M.E. (2019). Contractele de muncă atipice, Bucharest, Universul Juridic Publishing House.

Order No. 1109/2974/2020, published in Official Gazette, part I, no. 581 from 2 July 2020.

Order No. 456/2020, published in Official Gazette, part I, no. 484 of 9 June 2020.

The applicable measures at the UE level the site: https://ec.europa.eu/info/live-work-traveleu/health/coronavirus-response/recovery-plan-europe_ro.

Ştefănescu, I.T. (2017). Tratat teoretic şi practic de drept al muncii, (4 ${ }^{\text {th }}$ edition), Bucharest, Universul Juridic Publishing House, Bucharest. 